\title{
REGIONAL SMART SPECIALIZATION: MICROBUSINESS IMPACT
}

\author{
Yevheniia Polishchuk ${ }^{1}$, Alla Ivashchenko ${ }^{2}$, Anna Kornyliuk ${ }^{3}$
}

\begin{abstract}
SMART specialization is a basic approach to the development of regional innovation policy. It involves identifying priority sectors of the local economy with the involvement of key stakeholders. Currently, statistics on the development of regions are presented in terms of large business, small and medium. In this context, the generally accepted methodology from the Joint Research Center of the European Commission has limited application. Because it does not take into account the performance of microbusiness (individual entrepreneurs). For countries with economies in transition, this is critical, as they reach $80 \%$ of the business structure. Therefore, considering their voice is also necessary. Our approach involves a combination of quantitative (assessment of innovation and economic potential of the region) and qualitative (survey of microbusiness representatives) methods to identify priority areas of SMART specialization. Approbation of the offered method was carried out on the example of the Mykolaiv region which is in the south of Ukraine. The results of the study have shown that the innovation of microenterprises is at a low level. At the same time, they demonstrate a high level of desire to be involved in the process of SMART specialization and innovation of production.
\end{abstract}

Key words: innovations, regional development, SMART specialization, SMEs, microbusiness.

JEL Classification: R11, O32, O38

\section{Introduction}

In developed countries, a SMART specialization is an important tool to overcome regional development imbalances and improve their economic and social situation. The concept of SMART specialization provides a set of strategic programs based on the identification of the most promising and innovative industries for each region. That is why when selecting particular core sectors for the implementation of SMART specialization, it is critical to take into account the existing and potential level of innovation activities of the business in the region.

Microbusiness enterprises play a key role in the development of regional SMART specialization, as most of them are locally or socially rooted businesses and act as drivers of innovative transformations in the region. At the same time, they perform not only an economic but also an important social function the creation of jobs for the local community. At the same time, such individual entrepreneurs due to lack of managerial skills and low levels of financial strength experience are under the high level of bankruptcy risk in case of economic crisis, which in turn negatively affects the effectiveness of SMART specialization implementation in the region.

A key feature of SMART specialization is the ability of the regional business community to innovate. Unlike the use of aggregated statistical information, the use of survey method allows to obtain detailed information in the context of each microenterprise, which allows to identify and evaluate the main aspects of innovation activity of such companies in a much detailed way.

The article is structured as follows. Literature review section analyses papers on SMART specialization implementation and the role of main stakeholder in this process. Next section provides the methodology of the presented research and describes the main features of the survey. The last section provides the conclusions of the research.

\footnotetext{
Corresponding author:

${ }^{1}$ Kyiv National Economic University named after Vadym Hetman, Ukraine.

E-mail: polishchuk@kneu.edu.ua

ORCID: https://orcid.org/0000-0002-6133-910X

ResearcherID: J-5444-2018

${ }^{2}$ Kyiv National Economic University named after Vadym Hetman, Ukraine.

E-mail: alla.ivashchenko@kneu.edu.ua

ORCID: https://orcid.org/0000-0002-4599-7137

${ }^{3}$ Kyiv National Economic University named after Vadym Hetman, Ukraine.

E-mail: anna.kornyliuk@kneu.edu.ua

ORCID: https://orcid.org/0000-0001-8713-0681
} 


\section{Literature review}

A considerable amount of literature has been published on SMART specialization. A key aspect of SMART specialization is the collaboration between four main stakeholders: business, academic sector, NGOs and public authorities. The mutual performance is deeply studied in different papers.

There are a lot of papers where a certain country's process of SMART specialization is described. For instance, Almeida, Afonso and Silva (2020) put Portugal case in the focus of their research; Andryeyeva and Tiutiunnyk (2020) assess the innovation and investment potential in Ukrainian regions; Gedminaitė-Raudonè, Vidickienè \& Vilkè (2019) emphasize the unused potential of SMART specialization stakeholders in the case of Lithuania; some operational issues of SMART specialization in Finland are shown by Kaivo-Oja, Vähäsantanen, Karppinen, \& Haukioja, T. (2017); the input and output approach in SMART specialization analysis is applied on the example of the Western Balkans countries (2020); Mueller-Using, Urban, \& Wedemeier (2020) consider SMART specialization as an opportunity for better internalization of SMEs. One more interesting country aspect is examined by Martín, Orden-Cruz, \& Zergane (2020), where they research Islamic finance and Halal tourism as a bridge for SMART specialization.

Most studies on SMART specialization are conducted within general analysis of regional innovation policies and strategies in the EU countries and their regions (Benner, 2020; Gebhardt\& Stanovnik, 2016; Lepore \& Spigarelli, 2020; Gifford \& McKelvey, 2019). General approach of the EU Eastern cooperation is described in the paper of Prause (2014).

Several investigations of SMART specialization have shown significant increases in stakeholders' specifics in this process. It can be explained by the entrepreneurial discovery process which has started recently in the EU countries where stakeholders play a crucial role. For example, Farinha et al. (2020) explain how different groups of stakeholders assess the impact of SMART specialization on their regional development. Jeekabsone (2019) investigates the participation of different actors in policy making in the EU.

There are studies about certain groups of stakeholders participation in the SMART specialization process. For instance, Roman, Varga, Cvijanovic \& Reid (2020) regard the role of NGOs through the Quadruple Helix Models in the SMART specialization process. Zubareva, Kuramshina, \& Zavedeev (2020) reveal how SMEs modernize the regional economies through SMART specialization approaches. Marinelli \& ElenaPerez (2017) describe the participation of Catalonian universities in the entrepreneurial discovery process.
Another major study relates networks of SMART specialization stakeholders with regional productivity (Cortinovis \& Oort, 2018).

Overall, these studies show the versatility of such phenomena as SMART specialization and the role of stakeholders in this process. Nevertheless, worth mentioning that such stakeholders as individual entrepreneurs are missed in all regarded studies. For a country such as Ukraine, where more than $80 \%$ of businesses are individual entrepreneurs, it can cost wrong estimates of SMART specialization priorities. The statistics which are used for economic and innovation potential usually represents SMEs' performance, but not individual entrepreneurs because there is no appropriate data for SMART specialization priority assessment. Taking into account such a huge part of individual entrepreneurs and their possible role in this process, there is a need to hear their voice and measure their impact on regional innovation ecosystem development.

Therefore, the aim of the article is to evaluate the impact of individual entrepreneurs on regional innovation ecosystem development.

\section{Methods}

The study investigates the factors that affect the level and efficiency of microbusiness innovation activity on regional level.

The survey used web mode through Google Forms and was conducted among regional microbusiness representatives during July-August 2020. In total 380 individual entrepreneurs participated in the research. The distribution of respondents was as follows: $32 \%$ represented the manufacturing sector and $68 \%$ of respondents were engaged in various service sectors.

The questionnaire was designed by authors in consultation with the researchers from the Joint Research Centre of European Commission and based on close-ended questions of various types: singleand multiple-choice, matrix, dropdown. The survey design covers both quantitative data (e.g. number of employees, percentage of turnover that was invested in innovation activities) and qualitative data (e.g. types of introduced innovations, plans for further investments in innovations).

Data processing was conducted using exploratory analysis techniques.

\section{Features of microbusiness innovation activity within SMART specialization (case of Mykolaiv region)}

The survey of "Individual entrepreneurship in the development of innovation potential of Mykolaiv region" was conducted in order to identify the main features 
of performing innovation activity by microbusiness regarding assessment of regional potential within SMART specialization.

More than 380 Ukrainian individual entrepreneurs were interviewed to reveal problems concerning features of innovation implementation, ways of its funding, barriers and drivers for such activity as well as its possible impact on business KPIs. Along with this the possible impact of COVID-19 pandemic was estimated by interviewed individual entrepreneurs. As the result of the survey some problems related to innovation activity of microbusiness were identified.

The distribution of interviewed business representatives was presented by such spheres as light manufacturing/food industry - $16.6 \%$; trade $14.5 \%$; financial consulting/R\&D services - $12.5 \%$; heavy industry - 10. \%; services (including educational, law, entertainment, beautyetc.) - 10.4\%; transportation / logistics $-6.2 \%$; renewable energy / energy efficiency $5.2 \%$; construction $-5.2 \%$; transport repair $-4,16 \%$; IT - $4.1 \%$; medical sphere $-3.1 \%$, tourism - $2 \%$; other $-1.54 \%$.

More than $45 \%$ of respondents have had positive impact during last 3 years from business activity, namely becoming easier and more attractive for customers to use one of products or services (see Figure 1).

Considering the fact that multiplied choice was used by a lot of surveyed entrepreneurs, equal number of respondents exemplified as $37.4 \%$ improved characteristics of at least one of their products or services as well as improved at least one of their products by changing components and raw materials. About $27.5 \%$ business representatives improved the use of at least one of their products or services.

Respondents also indicated that $56 \%$ of them did not conduct any research projects, but $44 \%$ did some research, among which some entrepreneurs implemented from 1 to more than 3 research projects (Figure 2).

According to interview responses in each group a great share of entrepreneurs did not implement any research projects over the last 3 years, which means the low level of microbusiness innovativeness in Ukraine. However, respondents noted that 1 research project is the most numerical example of existent innovative activity of interviewed respondents ( $28 \%$ in avg.) in each group exemplified as completed, rejected or failed and projects in progress.

A lot of respondents pointed out that for the last 3 years they implemented 2 projects, in particular: $11.7 \%$ for completed projects, about $12 \%$ for rejected or failed projects and $16.6 \%$ for projects in progress from all received interview responses.

More than 3 research projects are typical for completed projects and for projects in progress, which share amounted $10.6 \%$ and $9.4 \%$ respectively.

About $33 \%$ of interviewed microbusiness representatives do not consider their activity as innovative one, which means that they have not been implementing innovation during the last 3 years. At the same time $67 \%$ from them conduct innovation activity which could benefit to regional innovation potential which has the great importance in process of industry selection in the context of SMART specialization. Almost $42 \%$ of them attracted outsourcing services in order to conduct innovation processes.

At least almost $41 \%$ of respondents cooperated with other firms and organizations to carry out joint research activity, only $11 \%$ of all interviewed businessman obtained investment sources from International Funds and about $21 \%$ of them cooperated with universities over the past 3 years.

From the authors' perspective, all these figures confirm the fact, that the level of cooperation and
Has it become easier and more attractive for customers to use one of your products or services?

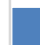

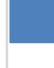

Improved the characteristics of one of your products or services?

Have you improved your products by changing components and raw materials?

Have you improved the use of one of your products or services?

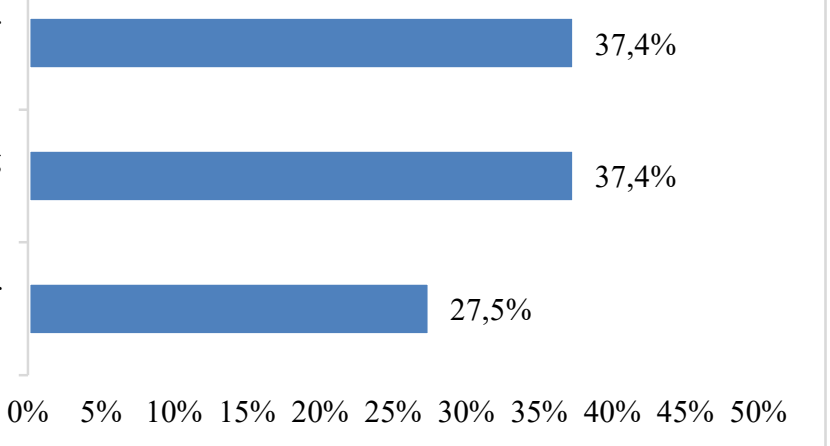

Figure 1. Entrepreneurial activity changes during the last 3 years 


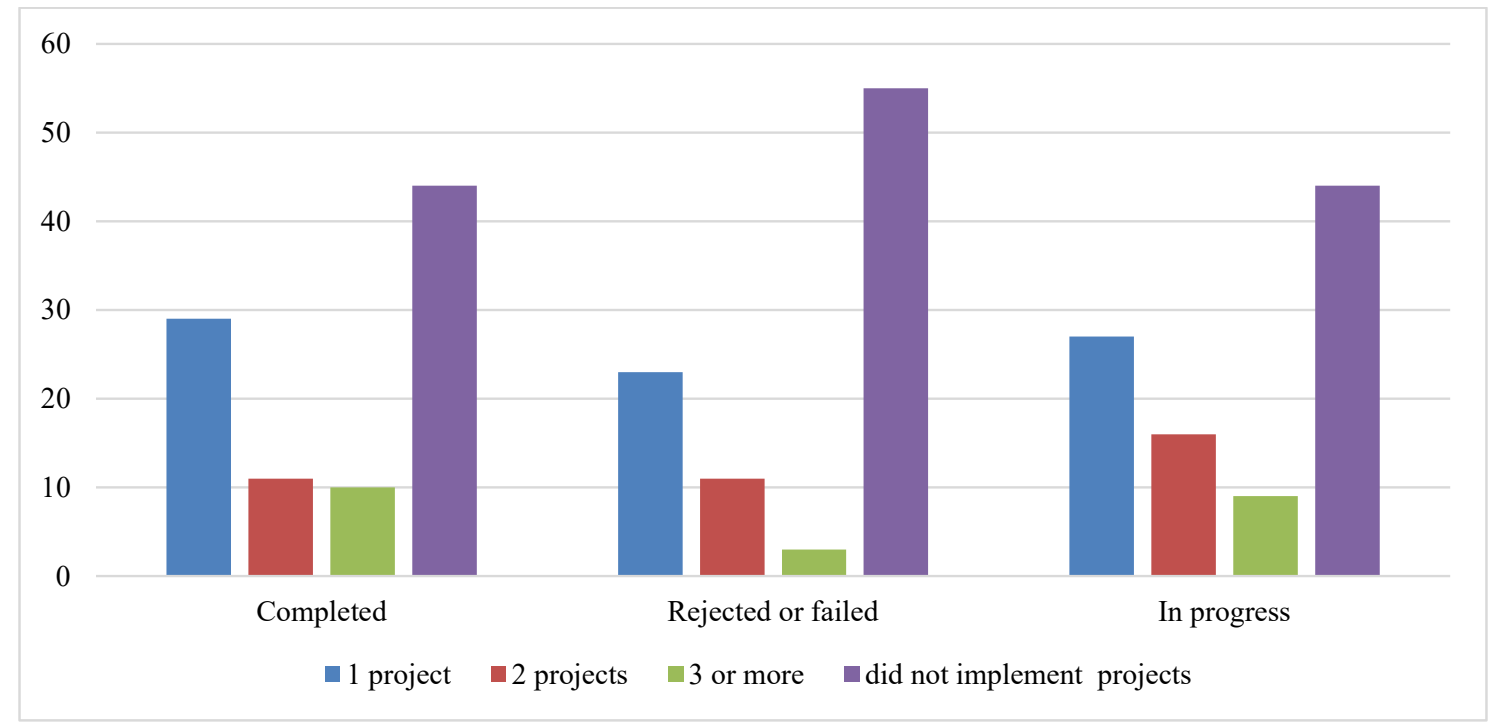

Figure 2. Number of research projects implemented in the last three years, units

collaboration between business, academia, other partners and companies is too low and the ability of microbusiness to obtain finance from International funds is very limited.

In accordance with interview responses, share of total turnover revenues for innovations were distributed in such way as shown on Figure 3 as well as possible impact of innovations on entrepreneurial activity (see Figure 4).

Conducted survey defined, that $67 \%$ of all respondents distributed about 1-10 \% of gross revenues to innovations, at the same time $14.3 \%$ of them $-11-20 \%$ and $18.7 \%$ - more than $20 \%$. So, the main share of interviewed entrepreneurs, who perform innovation activity, do not allocate a lot of funds for innovations.

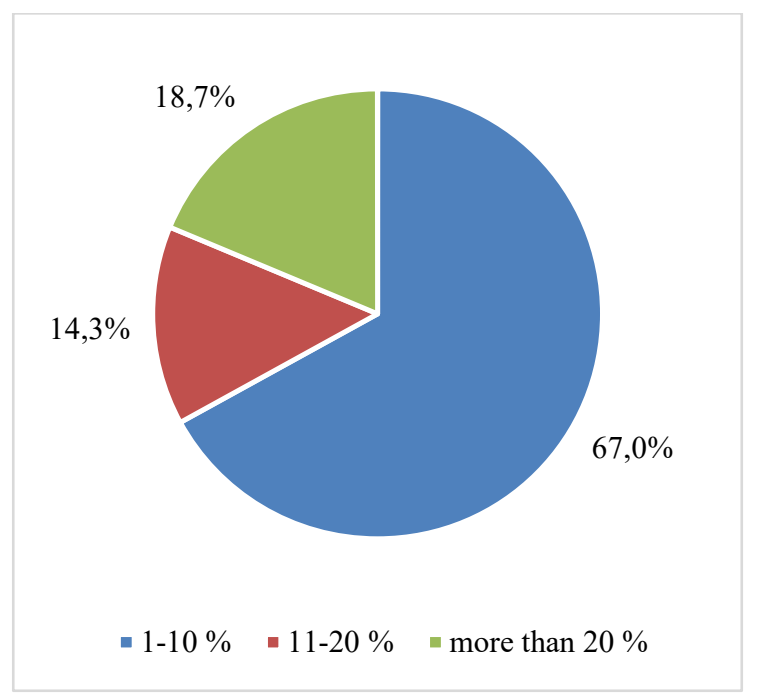

Figure 3. Share of total revenues distributed to innovation projects
The assessment of innovation impact on business activity shows, that entrepreneurs indicates that innovations effect: 1) attracting new customers $(29.7 \%) ; 2)$ income growth $(20.9 \%) ; 3$ ) entering new markets $(19.8 \%) ; 4)$ cost optimization $(12.1) ; 5)$ wage growth $(2.2 \%) .15 .4 \%$ of business representatives pointed out other reasons how innovations influence their business.

$79.1 \%$ of interviewed entrepreneurs have stated that the main sources of their innovation activity are their own sources; $15.4 \%$ of them successfully apply for grants; $11 \%$ get funding from bank loans and $17.6 \%$ consider other sources as the main funding for innovation performance (see Figure 5).

Among the main barriers for innovation development or/and implementation there were

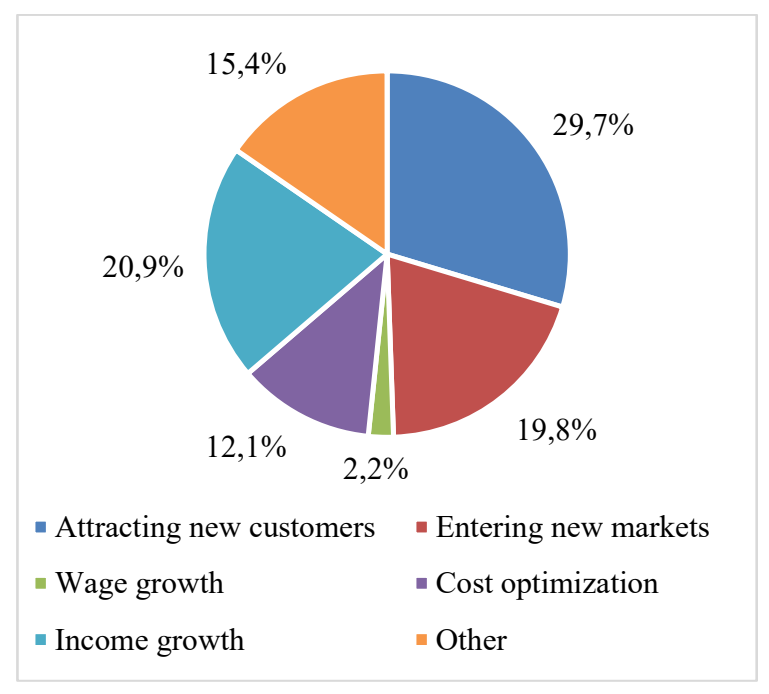

Figure 4. Impact of innovation implementation on entrepreneurial activity 


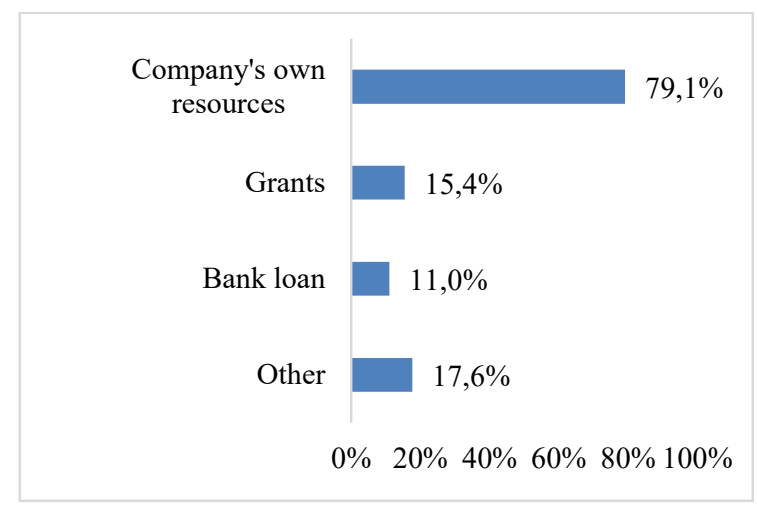

Figure 5. Sources of innovation funding

considered lack of funding (61.5\%); lack of knowledge and skills (27.5\%); no need of innovation activity (13.2\%) and other reasons (20.9\%). The results obtained from survey also define that only about $19 \%$ of respondents applied for patents in the last three years, which also proves the low innovation activity of microbusiness in Ukraine.

The low level of microbusiness innovativeness in Ukraine was aggravated by COVID-19 pandemic crisis. The expectations of microbusiness representatives are shown on Figure 7.

Taking into account survey responses, a lot of microbusiness representatives (34.1\%) expect that Covid-19 pandemic will lead to innovation expenses growth, but $27.5 \%$ of them suggest no changes for business activity.

At the same time $17.6 \%$ of interviewed respondents indicate that innovation expenses will be reduced and $12.1 \%$ will completely abandon innovation. $14.3 \%$ of respondents indicated other consequences for their business due to COVID-19 crisis.

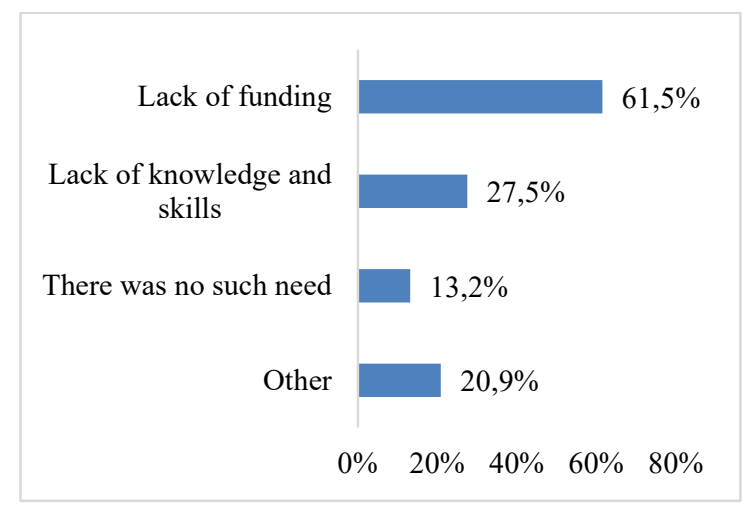

Figure 6. Obstacles for developing

(implementing) innovations

So, in the context of regional SMART specialization it is essential to promote innovations on regional level, especially in microbusiness which has ability to develop and implement innovation projects and which is not taken into account for official statistics. So, encouragement of cooperation and collaboration with other companies, universities, R\&D institutions, outsourcing companies on regional level could enforce the innovativeness level of microbusiness which might become drivers of regional economic development.

\section{Conclusions}

SMART specialization is impossible without the participation of key stakeholders (business, regional authorities, NGOs, academia). They must jointly identify the priority areas of development of the region. These directions concern the definition of the areas on which the regional innovation policy will be focused. Regional authorities should provide

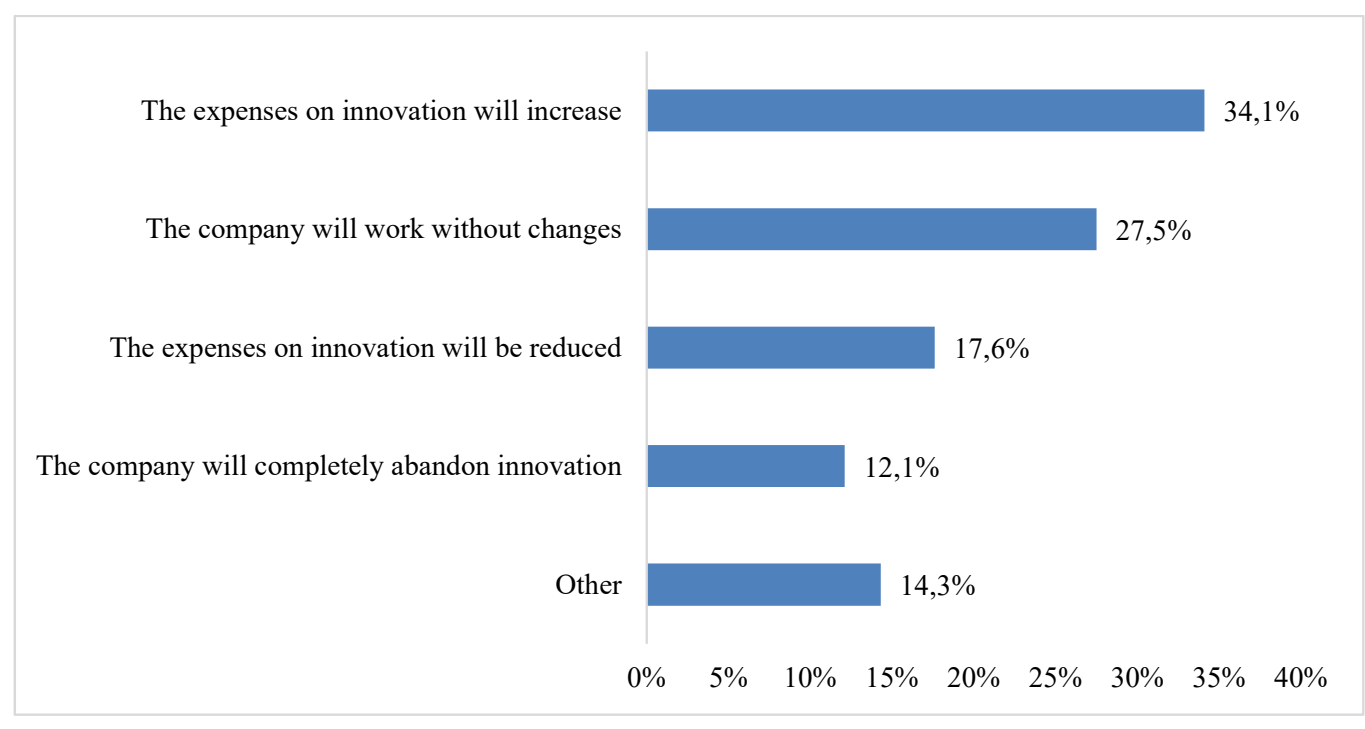

Figure 7. Expectations regarding the impact of COVID-19 on the innovative development 
institutional support for SMART specialization; nongovernmental organizations should support among civil society, the academic sector should provide research support and support in training necessary for the development of innovative industries; business should support this process financially. Creating institutional, financial and organizational preconditions for the implementation of regional innovation policy will help to bring the region to a new level of competitiveness not only at the national level but also globally. Correctness in setting priorities is extremely important.

The key requirement for the regional strategic planning in the context of SMART specialization approach is the as-is analysis and decent design of the business environment and innovation climate monitoring systems in the region in terms of key areas of innovation, cooperation with major stakeholders and sources of innovation projects funding. The proposed in the study approach allows to accurately assess the views of microbusiness on current and forecasted innovative development activities. Using newly-obtained data enables to apply an evidence-based approach to SMART specialization implementation and adjust it according to the changes in the regional business climate microbusiness views.

The survey results show that the level of microbusiness innovativeness in Mykolaiv region is extremely low due to the fact that a great share of individual entrepreneurs did not implement innovations at all or had implemented only one innovation project during the last 3 years. Taking into account the fact that innovations are mostly financed by own funds of microbusiness representatives and lack of funding is considered as the main constraint for innovation implementation, regional policy should be directed to enhancing innovation potential of individual entrepreneurs as well as their cooperation with other stakeholders.

In addition, it should be noted that individual entrepreneurs should be involved in public discussions with other potential stakeholders in the process of priority industry selection within SMART specialization because they could be the main drivers of regional innovation development. Such surveys should be conducted on a regular basis and can be used as the additional tool of qualitative analysis in order to provide more accurate expertise of regional development specifics identification.

\section{References:}

Almeida, A., Afonso, Ó, \& Silva, M. (2020). Operationalizing smart specialization in a Portuguese follower region. Panoeconomicus, OnLine-First Issue 00, pp. 14-14. doi: 10.2298/pan181109014a

Andryeyeva, N., \& Tiutiunnyk, H. (2020). Assessment of innovation and investment potentials as a strategic basis for identification of Smart Specialization of regions of Ukraine. Economics. Ecology. Socium, vol. 4(3), pp. 24-41. doi: 10.31520/2616-7107/2020.4.3-3

Benner, M. (2020). Six additional questions about smart specialization: Implications for regional innovation policy 4.0. European Planning Studies, vol. 28(8), pp. 1667-1684. doi: 10.1080/09654313.2020.1764506

Cortinovis, N., \& Oort, F. V. (2018). Between spilling over and boiling down: Network-mediated spillovers, local knowledge base and productivity in European regions. Journal of Economic Geography, vol. 19(6), pp. 1233-1260. doi: 10.1093/jeg/lby058

Farinha, L., Lopes, J., Sebastião, J. R., Ferreira, J. J., Oliveira, J., \& Silveira, P. (2020). How do stakeholders evaluate smart specialization policies defined for their regions? Competitiveness Review: An International Business Journal, Ahead-of-print. doi: 10.1108/cr-12-2019-0149

Gebhardt, C., \& Stanovnik, P. (2016). European Innovation Policy Concepts and the Governance of Innovation. Industry and Higher Education, vol. 30(1), pp. 53-66. doi: 10.5367/ihe.2016.0290

Gedminaitè-Raudonè, Ž., Vidickienè, D., \& Vilkè, R. (2019). Unused potential for Smart Specialization development through collaboration: Lithuanian case. Agricultural Economics (Zemédělská Ekonomika), vol. 65, no. 10, pp. 463-469. doi: 10.17221/98/2019-agricecon

Gifford, E., \& McKelvey, M. (2019). Knowledge-Intensive Entrepreneurship and S3: Conceptualizing Strategies for Sustainability. Sustainability, vol. 11(18), p. 4824. doi: 10.3390/su11184824

Gulc, A. (2015). Role Of Smart Specialisation In Financing The Development Of Regions In Perspective 2020. Business, Management and Education, vol. 13(1), pp. 95-111. doi: 10.3846/bme.2015.249

Ivashchenko, A. I., Polischuk, Y. A., \& Sybirianska, Y. V. (2017). Theoretical aspects of implementation of the innovation component evaluating model for small business enterprises. Marketing and Management of Innovations, vol. 2, pp. 160-171. doi: 10.21272/mmi.2017.2-15

Kholiavko, N., Djakona, A., Dubyna, M., Zhavoronok, A., \& Lavrov, R. (2020). The higher education adaptability to the digital economy. Bulletein of national academy of sciences of the Republic of Kazakhstan, vol. 4, no. 386, pp. $294-306$. Jēkabsone, I. (2019). Participation of Key Stakeholders In Science Policy Making In Eu. European Integration Studies, (13), 8-17. doi: 10.5755/j01.eis.0.13.23529

Kaivo-Oja, J., Vähäsantanen, S., Karppinen, A., \& Haukioja, T. (2017). Smart Specialization Strategy and its Operationalization in the Regional Policy: Case Finland. Business, Management and Education, vol. 15(1), pp. 28-41. doi: $10.3846 /$ bme.2017.362 
Lepore, D., \& Spigarelli, F. (2020). Integrating Industry 4.0 plans into regional innovation strategies. Local Economy: The Journal of the Local Economy Policy Unit, vol. 35(5), pp. 496-510. doi: 10.1177/0269094220937452 Mandras, G., \& Salotti, S. (2020). An Input-Output Analysis of Sectoral Specialization and Trade Integration of the Western Balkans Economies. Economies, vol. 8(4), p. 93. doi: 10.3390/economies8040093

Marinelli, E., \& Elena-Perez, S. (2017). Catalan universities and the entrepreneurial discovery process. Industry and Higher Education, vol. 31(6), pp. 360-372. doi: 10.1177/0950422217737150

Martín, J. C., Orden-Cruz, C., \& Zergane, S. (2020). Islamic Finance and Halal Tourism: An Unexplored Bridge for Smart Specialization. Sustainability, vol. 12(14), p. 5736. doi: 10.3390/su12145736

Mueller-Using, S., Urban, W., \& Wedemeier, J. (2020). Internationalization of SMEs in the Baltic Sea Region: Barriers of cross-national collaboration considering regional innovation strategies for smart specialization. Growth and Change. doi: 10.1111/grow.12439

Polishchuk, Y., Kornyliuk, A., \& Ivashchenko, A. (2020). Investor Relations Tools For Business In Smart Specialization Strategy. Baltic Journal of Economic Studies, vol. 6, no. 4, pp. 133-140. doi: 10.30525/22560742/2020-6-4-133-140

Polishchuk, Y., Kornyliuk, A., \& Britchenko, I. (2019). University as a core of E-learning ecosystem. 14th Conference on E-Learning - Unlocking the Gate to Education around the Globe, JUN 20-21, pp. 309-319.

Poponi, S., Arcese, G., Mosconi, E. M., \& Trifiletti, M. A. (2020). Entrepreneurial Drivers for the Development of the Circular Business Model: The Role of Academic Spin-Off. Sustainability, vol. 12(1), p. 423. doi: $10.3390 / \mathrm{su} 12010423$

Prause, G. (2014). Smart Specialization and EU Eastern Innovation Cooperation: A Conceptual Approach. Baltic Journal of European Studies, vol. 4(1), pp. 3-19. doi: 10.2478/bjes-2014-0001

Roman, M., Varga, H., Cvijanovic, V., \& Reid, A. (2020). Quadruple Helix Models for Sustainable Regional Innovation: Engaging and Facilitating Civil Society Participation. Economies, vol. 8(2), p. 48. doi: 10.3390/ economies 8020048

Zubareva, L. V., Kuramshina, A. V., \& Zavedeev, E. V. (2020). Small and medium-sized businesses in towns of commodity regions as source of diversification and modernization of their economy. Revista Amazonia Investiga, vol. 9(31), pp. 21-35. doi: 10.34069/ai/2020.31.07.2 